\title{
The Painful Side of Trap and Fixed Net Fisheries: Chronic Entanglement of Large Whales
}

\author{
Michael J. Moore and Julie M. van der Hoop \\ Biology Department, Woods Hole Oceanographic Institution, Woods Hole, MA 02543, USA \\ Correspondence should be addressed to Michael J. Moore, mmoore@whoi.edu \\ Received 5 January 2012; Accepted 5 April 2012 \\ Academic Editor: Frances Gulland
}

Copyright ( $) 2012$ M. J. Moore and J. M. van der Hoop. This is an open access article distributed under the Creative Commons Attribution License, which permits unrestricted use, distribution, and reproduction in any medium, provided the original work is properly cited.

Concern over the well-being of marine mammals at sea has focused on intentional harvests, both in terms of individual welfare and population sustainability. Unintentional mortalities from fishing gear entanglement are primarily seen as a risk to population viability. Additionally, larger whales breaking free of, and subsequently carrying, fixed trap and net gear are subject to a very slow demise, averaging 6 months in the case of the North Atlantic right whale (Eubalaena glacialis). Chronic cases can involve impaired foraging, increased drag, infection, hemorrhage, and severe tissue damage. The individual suffering of these cases appears to be extreme. Thus management measures should go beyond legally mandated conservation measures to include avoidance of such scenarios. Seafood consumers could succeed, where laws have failed, to demand fishing practices that do not kill whales in this manner. The effective absence of such demands would seem to reflect the cryptic nature of these cases to most consumers.

\section{Introduction}

Current debate [1] within animal welfare includes the concept that living conditions can be incrementally enhanced (Protectionism) versus the belief that such approaches only prolong animal suffering and that there needs to be a paradigm shift whereby animals are no longer owned and used (Abolitionism). Such debate focuses primarily on captive animals, both in the laboratory and on farms. However, there are parallels for wildlife, both terrestrial and marine. A number of factors need to be considered regarding the welfare of wildlife, including the nature of the harm caused, its duration, the numbers of animals affected, and their capacity for suffering [2]. These authors point out that most of the wildlife in the world today are under human influence, and we therefore have an obligation to consider their welfare in addition to that of domesticated animals. We quote Sainsbury et al. [3]: "the use of anticoagulant rodenticides, myxomatosis in rabbits, the poisoning of wildfowl by ingested lead shot, the contamination of seabirds with fuel oil, the effects of shooting, injuries due to collisions with road and vessel traffic and predation by domestic cats all severely compromise the welfare of large numbers of wild animals."
Feral cats provide a particularly poignant counterpoint, between concerns for their welfare, versus their impact on other wildlife such as song birds, and the impacts of trap, neuter, and return programs [4].

With regard to marine mammals, their welfare has been discussed in terms of their maintenance in captivity for display [5], especially in the context of the effects of long-term commercial confinement on Orcinus orca. Life expectancy has been reduced [5] in captive killer whales, and concern has been raised over behaviors of jaw popping and chewing of gate bars, which result in chronic dental decay [6], as well as periodic lethal aggression towards trainers [7]. The costs and benefits of marine mammal rehabilitation and release have also been reviewed [8]. For marine mammals in the wild there has been substantial concern about the sustainability of fishery bycatch [9]. There has, however, been less focus on the welfare concerns facing marine mammals at sea. Most such concern has focused on the various methods used in directed marine mammal harvests [10-12] where questions about the humane nature of such harvests have often been overlain and obfuscated with concerns about their sustainability. Previous papers have alluded to these welfare issues [13-15]. 
Drowning of small cetaceans and pinnipeds is of course a less than ideal manner of death, but it is at least usually quite quick, although substantially prolonged when compared to land mammals, given marine mammal adaptations for sustained diving [16]. Stress related to short-term entanglement of dolphins with mortality or subsequent release from tuna seines has also been widely studied $[17,18]$. In contrast, entanglement in debris and fishing gear can have a far longer time course for the most powerful larger species. Cassoff et al. [19] have detailed the pathobiology of chronic large whale entanglement in 21 cases from 4 species of baleen whale in the NW Atlantic.

Here the types and timelines of trauma documented by Cassoff et al. [19] are reviewed, and then discussed in the context of marine versus terrestrial animal welfare concerns and the differences in our societal responses to such trauma: when it is out of sight, at sea, compared to where it to be in plain view on land.

\section{The Nature of Large Whale Entanglement}

2.1. Drowning. If the animal is entangled in sufficient gear that it cannot break free of or swim the gear to the surface to breathe, it will drown. The evidence for this usually shows acute entanglement impact. Lesions often include one or more rope impressions, with the texture of the rope imprinted on the skin. Such imprints may be faint, and their detection can require a thorough external examination, often becoming less cryptic with different incident angles of light, and with the skin surface drying. Rope texture imprints, however, may be missing if the rope has been sawing back and forth as the animal struggles, causing deep skin, blubber, and muscle lacerations even down to the underlying bone, as has been modeled in the laboratory $[20,21]$. The carcass may or may not remain entangled on discovery. It may be found anchored in the gear, though animals are often cut loose postmortem to enable gear retrieval. Internal examination often reveals very little change. The trachea may have substantial froth, but there is usually an absence of inhaled water. Thus these drownings typically reflect asphyxiation. Often there is substantial bruising and edema underlying the areas compressed by the entangling gear, reflective of a functional circulation for some time after the initial entanglement but before death. Given that these species can all normally dive for tens of minutes, this is not surprising.

2.2. Emaciation. Entanglement involving the head region has been observed in $67 \%$ of all lethally entangled whales described by Cassoff et al. [19] and is the most common point of attachment for right whales [22]. This can result in direct reduction in feeding efficiency. Full wraps around the rostrum are not uncommon and can restrict mouth opening. Rope may foul the baleen filter, disrupt flow patterns, and limit the movement of the lips and tongue having direct impacts on feeding ability [23].

2.3. Increased Drag. Whales swim at a low drag coefficient [24-26], suggesting that the added drag of towing accessory gear could substantially affect the energy budget of an entangled large whale through time, as has been described for entangled fur seals [27]. Such an energy drain likely significantly contributes to the emaciation commonly seen with chronic entanglement [19]. Additionally, Lambersten et al. [23] have suggested that disruption of the oral seal, holding the lower mandible closed, could have a significant impact on propulsion efficiency and energy expenditure.

2.4. Infection and Severe Tissue Damage. Laceration and consequent infection can be another cause of death in chronic entanglement of large whales, with secondary bronchopneumonia [19]. Cases reported in North Atlantic right whales $[19,28]$ have included a taut line over the back between both axillae, dissecting off a $1.5 \mathrm{~m}$ sheet of blubber premortem. Commonly, where line is fixed to more than one body part, such as baleen and with multiple wraps around a flipper, the continual swimming motion of the animal induces a chronic laceration down to the limb bones, often the radius and ulna, with a subsequent massive proliferation of loose fibroosseous new periosteal bone (see cases 7, 8 and 11 in Cassoff et al., online supplement [19]).

2.5. Time Frame. Where drowning does not occur, lethally entangled right whales tend to die over periods of about 6 months $[13,19]$. There are cases where entanglement can persist for multiple years [29].

\section{Marine versus Terrestrial Contexts}

Many humans who are directly exposed to the realities of the pathology of the cases summarized above tend to be severely shocked by the inherent pain and suffering that they presumably represent for the individual animals in the time between initial entanglement and final demise. Documenting these case histories will lead to questioning all fishing practices responsible for such long drawn out trauma, pain and suffering. Thus it is worth reviewing the relevant legal and moral basis for why this situation persists in areas where powerful large whales, such as North Atlantic right whales, encounter anchored traps and nets.

North Atlantic right whale conservation is driven in the United States by attempts to conform to the Marine Mammal Protection Act of 1972 (MMPA) and the Endangered Species Act of 1973. In Canada, the recently enacted Species At Risk Act of 2003 is the legal mandate for right whale conservation, along with other endangered organisms. The MMPA does require consideration of humane treatment for specific scenarios, where "humane" is defined as "the least possible degree of pain and suffering practicable." Under the MMPA, the importation of a marine mammal must be humane and various sections allow that, in order to issue taking permits, the manner of the "take" must be humane. The U.S. Animal Welfare Act of 1996 as amended dictates suitable management of vertebrates in research and teaching contexts. However, the primary enforcement of all these laws for marine wildlife has been avoidance of species loss with little to no focus on the welfare aspects of incidental take in fisheries. 
Porter [30] classes cetaceans in the highest category of animals on a scale of sensibility to pain and suffering, from mollusks to primates. He describes them as sentient, highly intelligent and precognitive, in the same category as primates and carnivores. The degree to which it is possible to infer pain and suffering in wild animals has been reviewed by Kirkwood et al. [2]. These authors suggest summarizing cause, effect, level of stress and pain, and magnitude of the problem. In the case of large whale entanglement mortality, the cause is irreversible entanglement in fishing gear, the effect is ultimately lethal trauma through a drawn-out cumulative loss of body condition and constriction of body parts, with or without secondary infection, and the level of pain and stress is presumably extreme.

In a recent analysis (van der Hoop et al. unpublished data) entanglement was the leading cause of death in a suite of large whale species off the North American eastern seaboard. In addition, Knowlton et al. [31] have analyzed entanglements in North Atlantic right whales from photographs of entanglement scar incidence through time on living animals at sea. Between 1980 and 2004 at least $73 \%$ of 493 individuals were entangled at least once. The number of entanglements ranged from 1 to 6 per individual. Thus most self-disentangle or are disentangled by humans [32], with the entangling gear leaving visible, persistent scars. In the Knowlton study [31] the number of newly entangled animals in a given year ranged from 4 to $33 \%$ of the population. In SE Alaska at least 52\% of humpback whales have been entangled at least once, with an average of $8 \%$ of the population getting new entanglements every year [33]. Thus the lethal entanglement events are the extreme, and relatively infrequent end of a more widespread, persistent, and repetitive problem. The cost of nonlethal entanglement in terms of energy, stress, and pain, may significantly reduce fecundity in North Atlantic right whales, as this species reproduces at lower rates than southern right whales (Eubalaena australis) [34].

Consider the likely difference in response if the results of long standing right whale entanglements (i.e., emaciation, starvation, chronic pain, and infection) were observed on a daily basis by humans as they went about their lives in urban, suburban or rural communities rather than remaining out of sight at sea. If the equivalent of fixed fishery traps and nets was to be set on land, with a comparably slow and painful death for wildlife, the responsible industry could be subject to consumer revolt, irrespective of whether there was an actual law concerning such an interaction. However, a terrestrial precedent, that of coyotes conflicting with farming or ranching, where coyotes are poisoned and trapped, often with federal support, suggests that the politics of these interactions are very complex, and not necessarily based upon the welfare of individual wild animals.

The history of repeated attempts to ban leg-hold traps for terrestrial wildlife is salutary as reviewed by Gentile [35]. More than 450 antitrapping bills have been filed in the US Congress since 1900, but Gentile concluded that "the 99.98\% failure rate of antitrapping legislation can be attributed more to the inability of anti-trappers to unite than to a lack of popular support for their goal." Leg-hold traps are currently banned or restricted in only eight US states.

\section{Conclusion}

Chronic large whale entanglement, while unintentional, is cruel. Efforts to remedy the situation [36] have largely failed. Alternative remedies are available, specifically: consumer action, including boycotts, active publicity campaigns, and seafood certification. However, such efforts, such as the Marine Stewardship Council (MSC-http://www.msc.org/), to protect wild resources, can bring mixed results. The MSC has been criticized by environmental groups for certifying fisheries with debatable records and is currently considering providing certification to the lobster fisheries in the Gulf of Maine which have entangled large endangered whales. Better information about the nature and magnitude of the problem needs wider publicity and public awareness to begin to resolve these complex issues.

\section{Acknowledgments}

Support is gratefully acknowledged from Wick and Sloan Simmons and the North Pond Foundation.

\section{References}

[1] G. Francione and R. Garner, The Animal Rights Debate: Abolition Or Regulation? Columbia University Press, 2010.

[2] J. K. Kirkwood, A. W. Sainsbury, and P. M. Bennett, "The welfare of free-living wild animals: methods of assessment," Animal Welfare, vol. 3, no. 4, pp. 257-273, 1994.

[3] A. W. Sainsbury, P. M. Bennett, and J. K. Kirkwood, "The welfare of free-living wild animals in Europe: harm caused by human activities," Animal Welfare, vol. 4, no. 3, pp. 183-206, 1995.

[4] D. A. Jessup, “The welfare of feral cats and wildlife," Journal of the American Veterinary Medical Association, vol. 225, no. 9, pp. 1377-1383, 2004.

[5] Y. Jiang, M. Lück, and E. Parsons, "Public awareness, education, and marine mammals in captivity," Tourism Review International, vol. 11, no. 3, pp. 237-249, 2007.

[6] M. S. Graham and P. Dow, "Dental care for a captive killer whale, Orcinus orca," Zoo Biology, vol. 9, no. 4, pp. 325-330, 1990.

[7] J. Jett and J. Ventre, "Keto and Tilikum express the stress of Orca captivity," 2011, http://theorcaproject.wordpress.com/ 2011/01/20/keto-tilikum-express-stress-of-orca-captivity/.

[8] M. Moore, G. Early, K. Touhey, S. Barco, F. Gulland, and R. Wells, "Rehabilitation and release of marine mammals in the United States: risks and benefits," Marine Mammal Science, vol. 23, no. 4, pp. 731-750, 2007.

[9] A. J. Read, "The looming crisis: interactions between marine mammals and fisheries," Journal of Mammalogy, vol. 89, no. 3, pp. 541-548, 2008.

[10] S. K. Knudsen and E. O. Øen, "Blast-induced neurotrauma in whales," Neuroscience Research, vol. 46, no. 3, pp. 377-386, 2003.

[11] S. K. Knudsen, "A review of the criteria used to assess insensibility and death in hunted whales compared to other species," Veterinary Journal, vol. 169, no. 1, pp. 42-59, 2005. 
[12] R. Lambertsen and M. Moore, "Behavioral and post mortem observations on fin whales killed with explosive harpoons with preliminary conclusions concerning killing efficiency," IWC Technical Report TC/36/HK, 1983.

[13] M. J. Moore, A. Bogomolni, R. Bowman et al., "Fatally entangled right whales can die extremely slowly," in Proceedings of the Oceans'06, MTS/IEEE, Boston, Mass, USA, September 2006.

[14] M. Moore, "Current issues facing North Atlantic right whales and stakeholders," Boston College Environmental Affairs Law Review, vol. 36, pp. 309-317, 2009.

[15] M. Moore, "Welfare of whales bycaught in fishing gear or struck by vessels," Animal Welfare. In press.

[16] S. K. Hooker and R. W. Baird, "Diving and ranging behaviour of odontocetes: a methodological review and critique," Mammal Review, vol. 31, no. 1, pp. 81-105, 2001.

[17] M. A. Hall, "An ecological view of the tuna-dolphin problem: impacts and trade-offs," Reviews in Fish Biology and Fisheries, vol. 8, no. 1, pp. 1-34, 1998.

[18] D. J. St. Aubin, K. A. Forney, S. J. Chivers et al., "Hematological, serum, and plasma chemical constituents in pantropical spotted dolphins (Stenella attenuata) following chase, encirclement, and tagging," Marine Mammal Science. In press.

[19] R. M. Cassoff, K. M. Moore, W. A. McLellan, S. G. Barco, D. S. Rotstein, and M. J. Moore, "Lethal entanglement in baleen whales," Diseases of Aquatic Organisms, vol. 96, no. 3, pp. 175$185,2011$.

[20] J. P. Winn, B. L. Woodward, M. J. Moore, M. L. Peterson, and J. G. Riley, "Modeling whale entanglement injuries: an experimental study of tissue compliance, line tension, and drawlength," Marine Mammal Science, vol. 24, no. 2, pp. 326-340, 2008.

[21] B. L. Woodward, J. P. Winn, M. J. Moore, and M. L. Peterson, "Experimental modeling of large whale entanglement injuries," Marine Mammal Science, vol. 22, no. 2, pp. 299-310, 2006.

[22] A. Johnson, G. Salvador, J. Kenney et al., "Fishing gear involved in entanglements of right and humpback whales," Marine Mammal Science, vol. 21, no. 4, pp. 635-645, 2005.

[23] R. H. Lambertsen, K. J. Rasmussen, W. C. Lancaster, and R. J. Hintz, "Functional morphology of the mouth of the bowhead whale and its implications for conservation," Journal of Mammalogy, vol. 86, no. 2, pp. 342-352, 2005.

[24] P. J. O. Miller, M. P. Johnson, P. L. Tyack, and E. A. Terray, "Swimming gaits, passive drag and buoyancy of diving sperm whales Physeter macrocephalus," Journal of Experimental Biology, vol. 207, no. 11, pp. 1953-1967, 2004.

[25] K. A. Kermack, "The propulsive powers of blue and fin whales," Journal of Experimental Biology, vol. 25, no. 3, pp. 237-240, 1948.

[26] B. K. Ahlborn, R. W. Blake, and K. H. S. Chan, "Optimal fineness ratio for minimum drag in large whales," Canadian Journal of Zoology, vol. 87, no. 2, pp. 124-131, 2009.

[27] C. W. Fowler, "Marine debris and northern fur seals: a case study," Marine Pollution Bulletin, vol. 18, no. 6, supplement B, pp. 326-335, 1987.

[28] M. Moore, A. Knowlton, S. Kraus, W. McLellan, and R. Bonde, "Morphometry, gross morphology and available histopathology in Northwest Atlantic right whale (Eubalaena glacialis) mortalities (1970 to 2002)," Journal Cetacean Research and Management, vol. 6, pp. 199-214, 2004.

[29] Consortium, Right Whale Consortium Database, New England Aquarium, Central Wharf, Boston Mass, USA, 2012.
[30] D. G. Porter, "Ethical scores for animal experiments," Nature, vol. 356, no. 6365, pp. 101-102, 1992.

[31] A. Knowlton, M. Marx, H. Pettis, and P. K. Hamilton, "Scarification Analysis of North Atlantic Right Whales (Eubalaena glacialis): Monitoring Rates of Entanglement Interaction," Tech. Rep. 43EANF030107, National Marine Fisheries Service, England Aquarium, Central Wharf, Boston, Mass, USA, 2005.

[32] PCCS, 2011, http://coastalstudies.org/what-we-do/whalerescue/introduction.htm.

[33] J. L. Neilson, J. M. Straley, C. M. Gabriele, and S. Hills, "Nonlethal entanglement of humpback whales (Megaptera novaeangliae) in fishing gear in northern Southeast Alaska," Journal of Biogeography, vol. 36, no. 3, pp. 452-464, 2009.

[34] S. D. Kraus, P. K. Hamilton, R. D. Kenney, A. R. Knowlton, and C. K. Slay, "Reproductive parameters of the North Atlantic right whale," Journal of Cetacean Research and Management, vol. 2, pp. 231-236, 2001.

[35] J. R. Gentile, "The evolution of antitrapping sentiment in the United States: a review and commentary," Wildlife Society Bulletin, vol. 15, no. 4, pp. 490-503, 1987.

[36] NOAA, Atlantic Large Whale Take Reduction Plan, 2011, http://www.nero.noaa.gov/whaletrp/. 

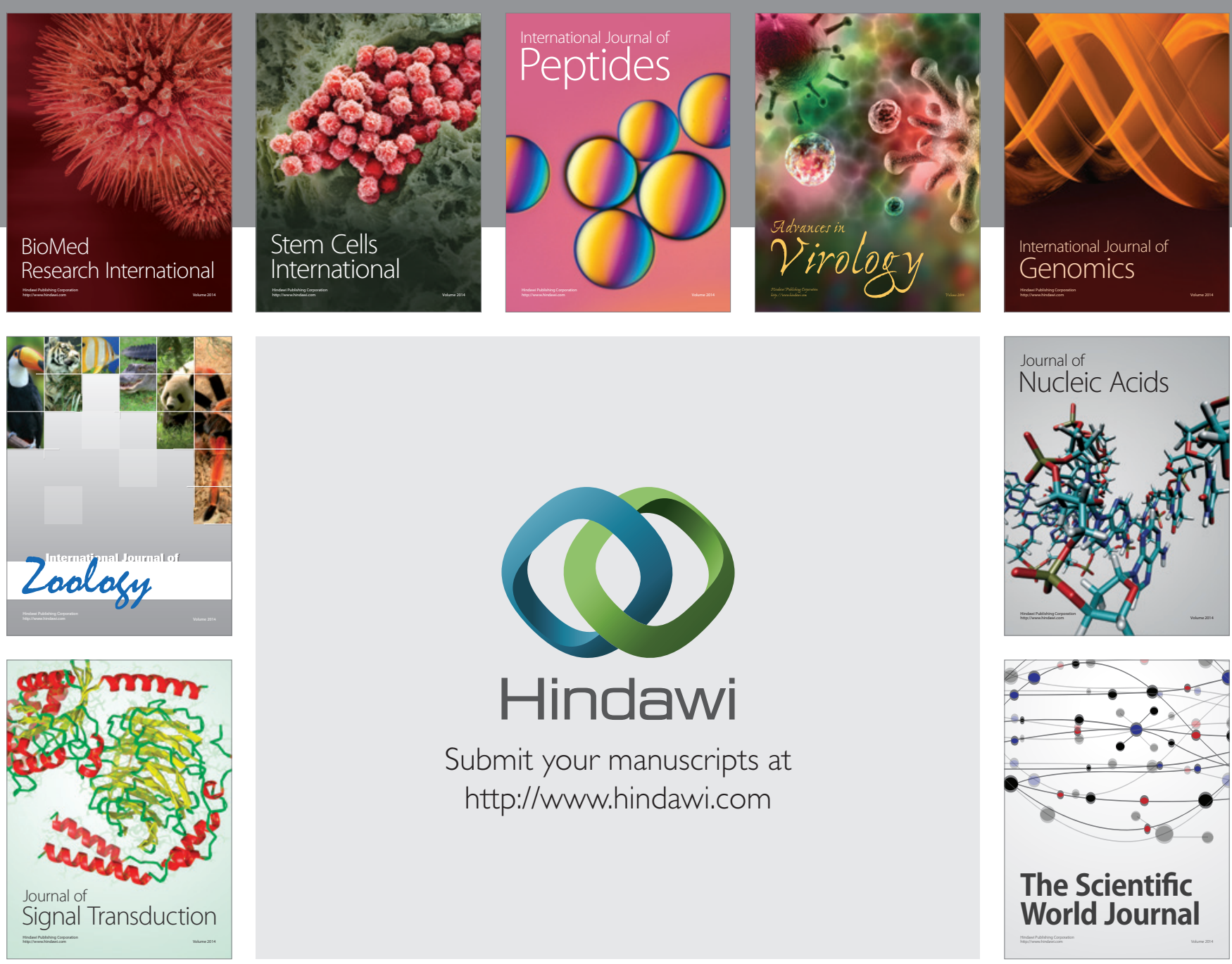

Submit your manuscripts at

http://www.hindawi.com
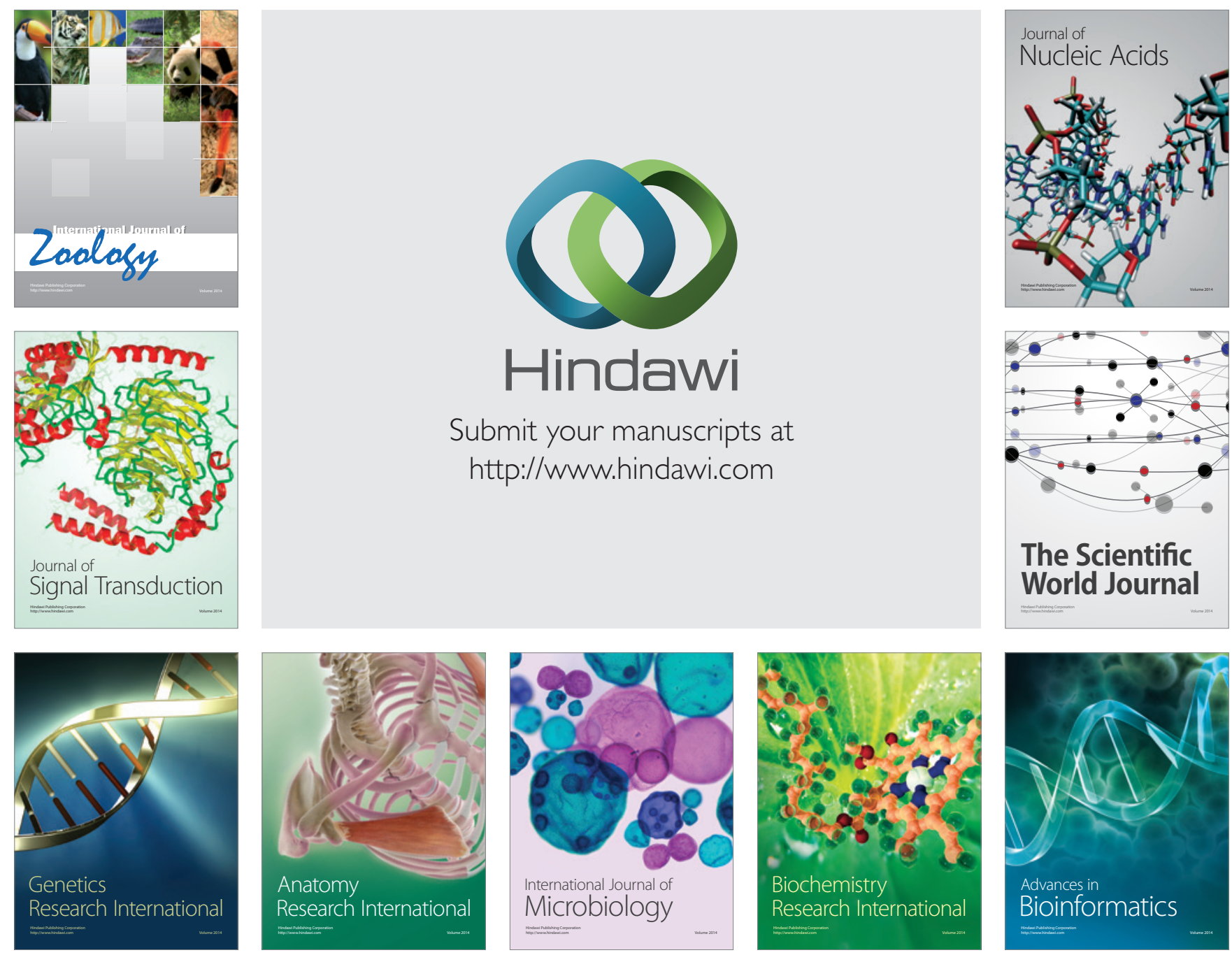

The Scientific World Journal
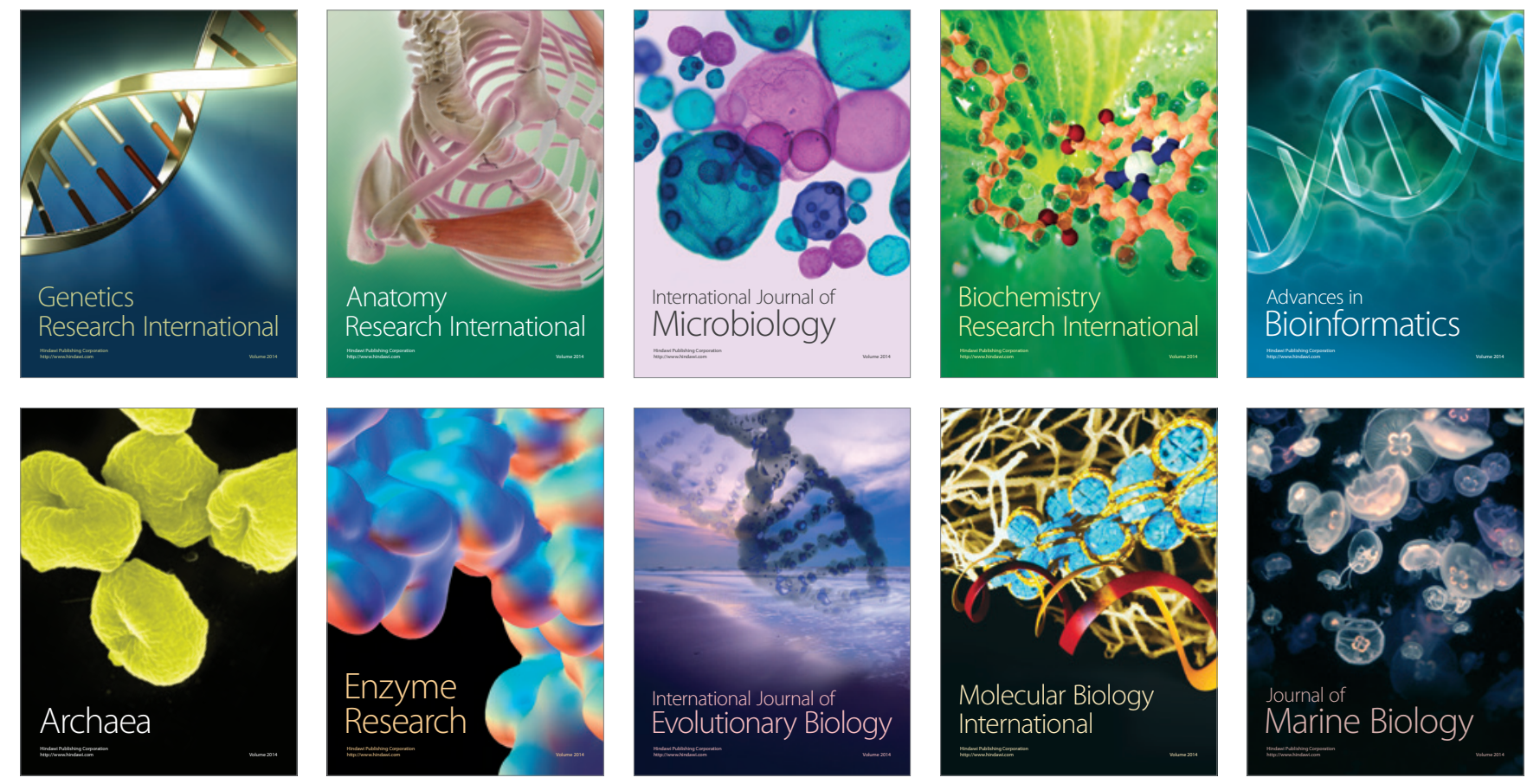